\title{
ALIF WITH AUTO-LOCKING CAGE WITHOUT SUPPLEMENTATION - TOMOGRAPHIC ANALYSIS OF INTERBODY BONE FUSION
}

\author{
ALIF COM CAGE AUTOBLOQUEANTE SEM SUPLEMENTAÇÃO - ANÁLISE TOMOGRÁFICA DE \\ FUSÃO ÓSSEA INTERSOMÁTICA
}

\section{ALIF CON CAJA CON AUTOBLOQUEO SIN COMPLEMENTACIÓN - ANÁLISIS TOMOGRÁFICO DE FUSIÓN ÓSEA INTERSOMÁTICA}

\author{
Luis Marchi ${ }^{1}$, Joes Nogueira-Neto ${ }^{1}$, Rodrigo Amaral ${ }^{1}$, Nicholal Faulhaber ${ }^{1}$, Etevaldo Coutinho ${ }^{1}$, Leonardo Oliveira ${ }^{1}$, Gabriel Pokorny ${ }^{1}$, \\ Rubens Jensen ${ }^{1}$, Luiz Pimenta ${ }^{1,2}$ \\ 1. Instituto de Patologia da Coluna (IPC), São Paulo, SP, Brazil \\ 2. University of California, San Diego, CA, USA
}

\begin{abstract}
Objective: The objective of this work is to study the fusion rate and complications of the mini-ALIF with an auto-locking device at the L5-S1 level. Methods: Retrospective and radiological study. The inclusion criteria were mini-ALIF in L5-S1 with auto-locking cage, DDD and/or low grade spondylolisthesis. The exclusion criteria were posterior/anterior supplementation; lack of 12-month follow-up images, and previous surgery at L5-S1 level. The primary endpoint was fusion assessed in CT images and/or lateral lumbar flexion/extension radiographs. The secondary endpoint was the revision surgery due to device movement/migration or pseudoarthrosis. Lumbar TCs and radiographs were analyzed during 12 months of follow-up. Fusion was defined according to Bridwell/Lenke classification. Results: Sixty-one cases were included in this study. Complete or ongoing fusion was found in 57 cases (93\%). Forty-two of the 61 levels (65\%) were completely fused after 12 months. Fifteen levels (28\%) had evident bone growth, two levels (3\%) showed lysis lines around the implant, and two levels (3\%) presented lysis lines and depression. Reoperation for pedicular screw supplementation was necessary in two cases (3\%), one with vertebral sliding progression (12 months), and one with symptomatic micro-movement (six months). No implant has undergone migration or expulsion of the disc space. Conclusions: Mini-ALIF in L5-S1 level using an auto-blocking interbody implant construction in cases of low segmental instability results in good interbody fusion index and low failure rate, even without the need for further supplementation, but should not be applied indiscriminately. Evidence Level: IV. Type of study: Case series.
\end{abstract}

Keywords: Spine; Arthrodesis; Computed tomography.

\section{RESUMO}

Objetivo: O objetivo deste estudo é estudar a taxa de fusão e complicações do mini-ALIF com dispositivo autobloqueante no nível L5S1. Métodos: Estudo radiológico e clínico retrospectivo. Inclusão: mini-ALIF feito em L5S1 com cage autobloqueante; DDD e/ou espondilolistese de baixo grau. Exclusão: suplementação posterior/anterior; falta de imagens de 12 meses; cirurgia prévia no nível L5S1. O desfecho primário foi fusão avaliada em exames de TC elou radiografias lombares laterais de flexão/extensão. Desfecho secundário foi cirurgia de revisão, devido movimento/migração do dispositivo ou pseudoartrose. Tomografias e radiografias lombares foram analisadas em 12 meses. Fusão foi definida de acordo com classificação de Bridwell/Lenke. Resultados: 61 casos incluídos neste estudo. Fusão completa ou em curso foi encontrada em 57 casos (93\%). 42 dos 61 níveis (65\%) estavam completamente fusionados após 12 meses. 15 níveis (28\%) tiveram crescimento ósseo evidente, dois níveis (3\%) mostraram linhas de lise ao redor do implante, e dois níveis (3\%) apresentaram linhas de lise e afundamento. Reoperação para suplementação com parafusos pediculares foi necessária em dois casos (3\%) - um com progressão do deslizamento vertebral (12 meses) e outro com micro movimentação sintomático (seis meses). Nenhum implante sofreu migração ou expulsão do espaço discal. Conclusões: mini-ALIF em L5S1 usando uma construção com implante intersomático auto-bloqueante, em casos de baixa instabilidade segmentar, resulta em bom índice de fusão intersomática e baixo índice de falha, mesmo sem a necessidade de suplementação posterior, mas não deve ser aplicado indiscriminadamente. Nivel de Evidência: IV. Tipo de estudo: Série de casos.

Descritores: Coluna; Artrodese; Tomografia computadorizada.

\section{RESUMEN}

Objetivo: El objetivo de este trabajo es estudiar la tasa de fusión y las complicaciones de la mini-ALIF con un dispositivo de autobloqueo en el nivel L5-S1. Métodos: Estudio retrospectivo y radiológico. Los criterios de inclusión fueron mini-ALIF en L5-S1 con caja con mecanismo de autobloqueo, DDD y/o espondilolistesis de bajo grado. Los criterios de exclusión fueron complementación posterior/anterior, falta de imágenes de seguimiento de 12 meses y cirugía previa en el nivel L5-S1. El criterio principal de valoración fue la evaluación de la fusión en imágenes de TC y/ o radiografías lumbares laterales en flexión/extensión. El criterio secundario de valoración fue la cirugía de revisión debido al movimiento/migración del dispositivo o la pseudoartrosis. Las tomografías y radiografías lumbares se analizaron durante 12 meses. La fusión fue definida de acuerdo con la clasificación de Bridwell/Lenke. Resultados: Sesenta y un casos fueron incluidos en este estudio. Se encontró fusión completa o en curso en 57 casos (93\%). Cuarenta y dos de los 61 niveles (65\%) estaban completamente fusionados 
después de 12 meses. Quince niveles (28\%) tuvieron crecimiento óseo evidente, dos niveles (3\%) mostraron líneas de lisis alrededor del implante y dos niveles (3\%) presentaron líneas de lisis y hundimiento. La reintervención para la complementación con tornillos pediculares fue necesaria en dos casos (3\%), uno con progresión de deslizamiento vertebral (12 meses) y uno con micro-movimiento sintomático (seis meses). Ningún implante ha sufrido migración o expulsión del espacio discal. Conclusiones: La mini-ALIF en nivel L5-S1 utilizando una construcción de implante intersomático con mecanismo de autobloqueo en casos de baja inestabilidad segmentar resulta en buen índice de fusión intersomática y bajo índice de fallo, incluso sin la necesidad de complementación, pero no debe aplicarse indiscriminadamente. Nivel de Evidencia: IV: Tipo de estudio: Serie de Casos.

Descriptores: Columna vertebral; Artrodesis; Tomografía computarizada.

\section{INTRODUCTION}

Interbody fusion is a surgical procedure in which a discectomy and the placement of a cage at the level of interest are performed with the goal of fusing the vertebrae and thus immobilizing the segment. The purpose of the procedure is to cure or minimize the pain caused by a pathological movement and to restore disc height, thus promoting indirect decompression. ${ }^{1}$ Several surgical techniques can be used to achieve this fusion, among them anterior lumbar interbody fusion (ALIF). ${ }^{2}$ and is one of the most frequent causes of disability. Lumbar spondylosis may result in mechanical back pain, radicular and claudicant symptoms, reduced mobility and poor quality of life. Surgical interbody fusion of degenerative levels is an effective treatment option to stabilize the painful motion segment, and may provide indirect decompression of the neural elements, restore lordosis and correct deformity. The surgical options for interbody fusion of the lumbar spine include: posterior lumbar interbody fusion (PLIF Anterior) access is indicated for the more distal levels of the spine and offers several advantages as compared with other approaches, among them the possibility of a wide discectomy, a greater gain in lordosis at the level of interest, a low risk of injury to the posterior neural structures, and less risk of lesion of the posterior musculature that supports the spine. ${ }^{3-4}$ However, there are several disadvantages to this approach. The most commonly cited in the literature include the danger of bleeding due to the proximity to large blood vessels and the possibility of retrograde ejaculation from the chance of damage to the hypogastric nerve that passes in front of the spine..$^{2-5}$

In an attempt to reduce morbidity and interoperative complications from the surgical approach, less invasive techniques like as the anterior retroperitoneal approach for lumbar fusion (mini-ALIF) have evolved. This option consists of a smaller incision, blunt dissection of the abdominal muscles, and retroperitoneal access to reach the spine, which, together, require less surgical time and result in less interoperative bleeding. ${ }^{6-7}$ These factors not only reduce the possible complications, but also sustain a good rate of surgical success.

In general, after the discectomy and introduction of the cage, pedicle screws are usually used posteriorly for the fixation of the operated level. However, although quite stable, this option has disadvantages when compared to the stand-alone alternative (without supplementation). ${ }^{1}$ Currently, there are biomechanically viable options with cages with auto-locking screws that provide enough stability for use without the need for additional fixation. ${ }^{8}$ Despite well-established biomechanical data, few studies have evaluated the clinical and radiological advancements in anterior approach interbody fusion using auto-locking devices. Thus, the objective of this study was to evaluate solid fusion of the L5-S1 level through mini-ALIF with an auto-locking device.

\section{METHODS}

This was a retrospective radiological study conducted in a single center. It was analyzed and approved by the Institutional Review Board (IRB no. 52909516.3.0000.5551) and the ICF requirement was waived.

The cases $(n=61)$ were selected according to the following inclusion criteria: an indication of surgical treatment at a single level in L5-S1 for degenerative disc disease (DDD) and/or low grade spondylolisthesis; an indication of anterior lumbar interbody fusion (mini-ALIF) without additional supplementation using an auto-locking titanium alloy cage with an angulation of $15^{\circ}$ lordosis (MDT Implantes,
LAS Brasil, São Paulo, SP, Brazil); the absence of prior surgery at the level of interest; the presence of perioperative $\mathrm{X}$-rays and computer tomography (CT) and/or 12-month postoperative follow-up lateral lumbar flexion/extension radiographs. The exclusion criteria were posterior or anterior supplementation, previous surgery at level L5-S1, and lack of 12-month images.

The primary endpoint was fusion evaluated in computed tomography (CT) images and/or in lateral lumbar flexion/extension radiographs. The secondary endpoint was the presence/absence of revision surgery for the movement/migration of the device or for pseudoarthrosis. Lumbar radiography and tomography studies were analyzed after 12 months. Fusion was defined according to the Bridwell/Lenke classification. ${ }^{9}$

\section{RESULTS}

Table 1 shows the data from the group studied in this work. Sixtyone patients with an average age of 44.3 years, 37 (61\%) of them women, were included. Of these, 46 cases $(75 \%)$ had been diagnosed with DDD and 15 (25\%) with low-grade spondylolisthesis. All cases underwent interbody fusion at level L5-S1 by single access anterior approach. Auto-locking cages with cortical screws were used for fixation without the necessity for posterior approach. All cases had a minimum follow-up time of 12 months.

Table 2 displays the results for fusion rates according to the Bridwell-Lenke classification. Complete or ongoing fusion was observed in 57 cases (93\%). According to the Bridwell/Lenke classification, 42 levels (65\%) were judged completely fused in the CT 12 months following surgery (grade I) (Figures 1 and 2). Fifteen levels (28\%) had ongoing bone growth (grade II), two levels (3\%) showed lucency and collapse (grade IV).

Posterior surgical reapproach for supplementation with pedicle screws (Figure 3) was necessary in two cases (3\%) - one with progression of vertebral slippage (at 12 months) and the other with symptomatic micromovement (at six months). No interbody implant suffered migration or expulsion for the disc space.

Table 1. Demographic data of the group studied.

\begin{tabular}{c|c}
\hline Cases & 61 \\
\hline Age & $44.3( \pm 12.3)$ \\
\hline Sex (F/M) & $37(61 \%) / 24(39 \%)$ \\
\hline Pathology & \\
\hline DDD & $46(75 \%)$ \\
\hline Spondylolisthesis & $15(25 \%)$ \\
\hline
\end{tabular}

Table 2. Interbody fusion rate, according to the Bridwell-Lenke classification.

\begin{tabular}{c|c|c}
\hline Grade & $\mathrm{n}$ & $\%$ \\
\hline I & 42 & $65 \%$ \\
\hline II & 15 & $28 \%$ \\
\hline III & 2 & $3 \%$ \\
\hline IV & 2 & $3 \%$ \\
\hline
\end{tabular}



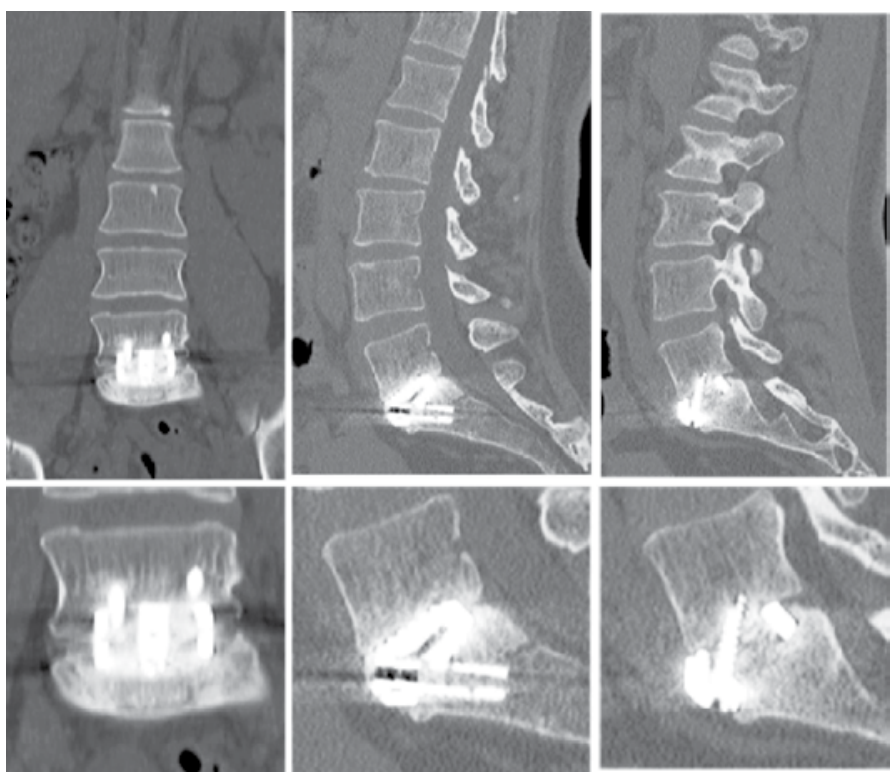

Figure 1. Example of a case showing solid bone fusion (grade I) at the 12-month postoperative follow-up.
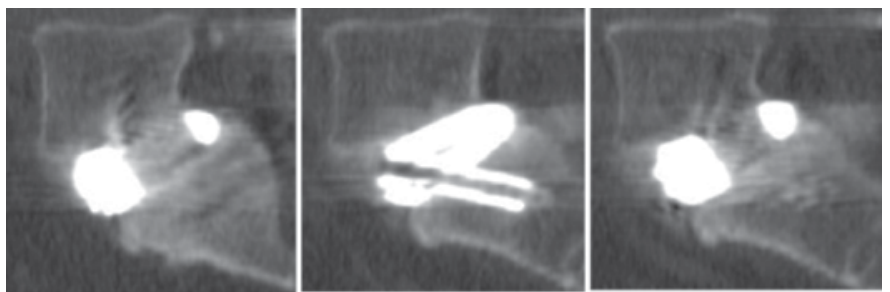

Figure 2. Example of a case showing solid bone fusion (grade I) at the 12-month postoperative follow-up.
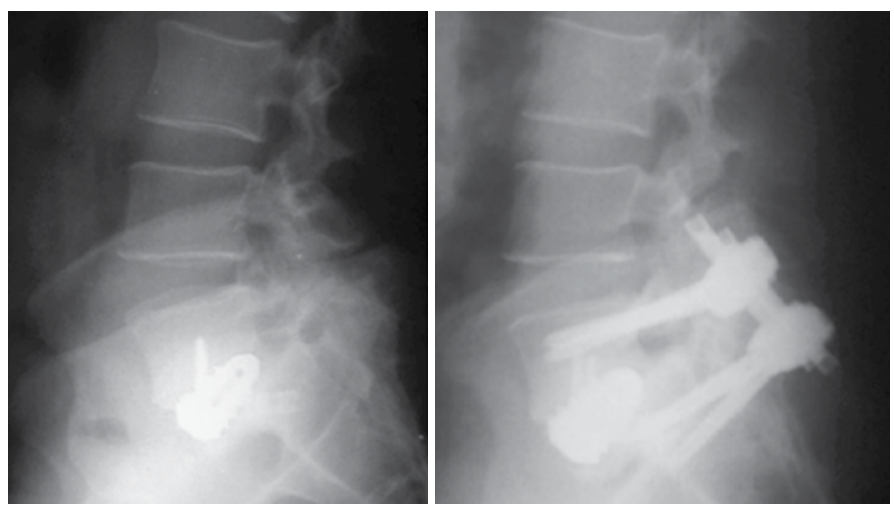

Figure 3. Example of a case requiring stabilization with transpedicle screws.

\section{DISCUSSION}

This study evaluated interbody fusion in patients who underwent single access anterior mini-ALIF with an auto-locking cage at level L5-S1 without any additional posterior fixation. In total, the rate of complete or ongoing fusion (grade I and II) was 93\% and only 3\% experienced adverse events requiring a surgical reapproach. None of the implants migrated or was displaced from the location where it had been fixed.
The use of anterior access to treat degenerative disc disease and spondylolisthesis was described in the 1930s in studies by Carpenter, Mercer, and Burns. ${ }^{10-12}$ Over the years, anterior access was improved into a less invasive form, the mini-ALIF, that uses a retroperitoneal approach with blunt dissection of the abdominal wall muscles and a smaller skin incision, with low complication rates. ${ }^{13-14}$ This technique has gained many adepts over the years and, in parallel, interbody spacers have evolved from the bone graft blocks used in the early days of the technique, to the first synthetic threaded cages (BAK), to the auto-locking PEEK (polyetheretherketone) and titanium alloy cages currently being used. ${ }^{15}$

Self-locking cages with screws directed to the adjacent vertebral bodies offer stability comparable to an ALIF with fixation with pedicle screws in movements of flexion, extension, and lateral inclination and they present superior biomechanical properties in rotation. ${ }^{16}$ Additionally, a study observed that these auto-locking cages could distribute the load like an intact lumbar disc. ${ }^{8}$

Auto-locking cages enable interbody fusion for a single access and can deliver better clinical outcomes and a similar fusion rate when compared to anterior approach arthrodesis in combination with posterior fixation with pedicle screws in single level cases. ${ }^{17}$ The percentage of fusion observed in our study is comparable to others reported in the literature. Allain et al. conducted a prospective study in which 65 patients were followed-up for 12 months and the authors observed a fusion rate at the end of this period of $93.3 \%{ }^{18}$ Likewise, Rao et al. reported a fusion rate of $91 \%$ in patients submitted to ALIF for the treatment of spondylolisthesis ${ }^{19}$ and a death rate similar to that of our study.

This fusion rate is comparable to that of techniques widely used in clinical practice, such as TLIF (Transforaminal Lumbar Interbody Fusion) with the presence of pedicle screws for posterior. ${ }^{20}$ However, the success rate observed in these studies is not as high in more extensive arthrodeses, and so it is not recommended without additional posterior supplementation. ${ }^{21}$

The observation of both growth and solid bone fusion has been put in check because of the lack of a simple and direct correlation with better clinical outcomes. However, complementary to this discussion, evolution with instability, migration of the device, or pseudoarthrosis may indeed be deleterious in certain cases. Importantly, in this study there were no cases of migration or breakage of the implanted cages, although two cases required surgical reapproach for posterior pedicle fixation, one due to pseudoarthrosis, and the other to the presence of micromovement causing pain.

Two limitations of this study should be highlighted: the retrospective design and limited number of cases analyzed. Prospective, multicenter studies with a greater number of cases should be conducted with more data about achieving bone fusion using auto-locking implants for anterior approach lumbar fusion.

\section{CONCLUSIONS}

The interbody fusion of L5-S1 using mini-ALIF with an auto-locking implant without the use of pedicle screws can achieve a good bone fusion rate and a low reoperation rate in selected cases. Single access for the fusion of L5-S1 can be performed without the need for posterior supplementation in cases of low segmental instability.

Author Luiz Pimenta declares that he receives royalties from the manufacturer (MDT Implantes) of a prosthesis similar to that presented in this article. The other authors declare no potential conflict of interest related to this article.

CONTRIBUTION OF THE AUTHORS: Each author made significant individual contributions to this manuscript. LM(0000-0002-3447-0399)* and JNN (0000-0001-7090-2833)* were the main contributors to the writing of the manuscript. LP (0000-0002-5702-5431), RA(0000-0003-3007-0571)*, RJ (0000-0002-2313-7793)*, NF( 0000-0002-7401-3993)*, and EC (0000-0002-1768-1741)* performed the surgeries, followed up with the patients, and gathered clinical data. LM conducted the bibliographical research. LM, LO(0000-0002-3230-3765)*, JNN, RA, GP( 0000-0002-7907-8032* and LP contributed to the intellectual concept of the study. All authors participated actively in the discussion of results, review, and approval of the version of the manuscript submitted. *ORCID (Open Researcher and Contributor ID). 


\section{REFERENCES}

1. Kerolus M, Turel MK, Tan L, Deutsch H. Stand-Alone Anterior Lumbar Interbody Fusion: Indications, Techniques, Surgical Outcomes and Complications. Expert Rev Med Devices. 2010;13(12):1127-1136.

2. Mobbs RJ, Phan K, Malham G, Seex K, Rao PJ. Lumbar interbody fusion: techniques, indications and comparison of interbody fusion options including PLIF, TLIF MI-TLIF, OLIF/ATP, LLIF and ALIF. J Spine Surg Hong Kong. 2015;1(1):2-18.

3. Udby PM, Bech-Azeddine R. Clinical outcome of stand-alone ALIF compared to posterior instrumentation for degenerative disc disease: A pilot study and a literature review. Clin Neurol Neurosurg. 2015;133:64-9.

4. Jiang S-D, Chen J-W, Jiang L-S. Which procedure is better for lumbar interbody fusion: anterior lumbar interbody fusion or transforaminal lumbar interbody fusion? Arch Orthop Trauma Surg. 2012;132(9):1259-66.

5. Kain C, Giesler B, Hochschuler SH. Anterior lumbar interbody fusion: lumbar approach, complications, and their prevention. Oper Tech Orthop. 1993;3(3):225-231.

6. Smith WD, Christian G, Serrano S, Malone KT. A comparison of perioperative charges and outcome between open and mini-open approaches for anterior lumbar discectomy and fusion. J Clin Neurosci Off J Neurosurg Soc Australas. 2012 [acesso em: 8 de fevereiro de 2012]; Disponível em: http://www.ncbi.nlm.nih.gov/pubmed/22236486

7. Brau SA. Mini-open approach to the spine for anterior lumbar interbody fusion: description of the procedure, results and complications. Spine J Off J North Am Spine Soc. 2002;2(3):216-23.

8. Choi K-C, Ryu K-S, Lee S-H, Kim YH, Lee SJ, Park C-K. Biomechanical comparison of anterior lumbar interbody fusion: stand-alone interbody cage versus interbody cage with pedicle screw fixation -- a finite element analysis. BMC Musculoskelet Disord. 2013;14:220.

9. Bridwell KH, Lenke LG, McEnery KW, Baldus C, Blanke K. Anterior fresh frozen structura allografts in the thoracic and lumbar spine. Do they work if combined with posterior fusion and instrumentation in adult patients with kyphosis or anterior column defects? Spine. 1995:20(12):1410-8.

10. Burns BH. An operation for spondylolisthesis. The Lancet. 1933;221(5728):1233.

11. Capener N. Spondylolisthesis. Br J Surg. 1932;19(75):374-86.
12. Mercer W. Spondylolisthesis: with a description of a new method of operative treatment and notes of ten cases. Edinb Med J. 1936:43:545-72.

13. Amaral R, Ferreira R, Marchi L, Jensen R, Nogueira-Neto J, Pimenta L. Artrodese lombar intersomática anterior por via única - Complicações e resultados perioperatórios. Rev Bras Ortop. 2017 [Acesso em: 30 de junho de 2017]; ahead of publish. Disponível em: http://www.sciencedirect.com/science/article/pii/S0102361616302417.

14. Baaj AA, Dakwar E, Le TV, Smith DA, Ramos E, Smith WD, et al. Complications of the mini-open anterolateral approach to the thoracolumbar spine. J Clin Neurosci Off J Neurosurg Soc Australas. 2012;19(9):1265-7.

15. Phan K, Mobbs RJ. Evolution of Design of Interbody Cages for Anterior Lumbar Interbody Fusion. Orthop Surg. 2016;8(3):270-7.

16. Cain CMJ, Schleicher P, Gerlach R, Pflugmacher R, Scholz M, Kandziora F. A new standalone anterior lumbar interbody fusion device: biomechanical comparison with established fixation techniques. Spine. 2005;30(23):2631-6.

17. Strube $P$, Hoff E, Hartwig T, Perka CF, Gross C, Putzier M. Stand-alone anterior versus anteroposterior lumbar interbody single-level fusion after a mean follow-up of 41 months. J Spinal Disord Tech. 2012;25(7):362-9.

18. Allain J, Delecrin J, Beaurain J, Poignard A, Vila T, Flouzat-Lachaniette C-H. Standalone ALIF with integrated intracorporeal anchoring plates in the treatment of degenerative lumbar disc disease: a prospective study on 65 cases. Eur Spine $\mathrm{J}$ Off Publ Eur Spine Soc Eur Spinal Deform Soc Eur Sect Cerv Spine Res Soc. 2014:23(10):2136-43.

19. Rao PJ, Ghent F, Phan K, Lee K, Reddy R, Mobbs RJ. Stand-alone anterior lumbar interbody fusion for treatment of degenerative spondylolisthesis. J Clin Neurosci Off J Neurosurg Soc Australas. 2015;22(10):1619-24.

20. Phan K, Thayaparan GK, Mobbs RJ. Anterior lumbar interbody fusion versus transforaminal lumbar interbody fusion - systematic review and meta-analysis. $\mathrm{Br} J$ Neurosurg. 2015;29(5);705-11.

21. McCarthy MJH, Ng L, Vermeersch G, Chan D. A radiological comparison of anterior fusion rates in anterior lumbar interbody fusion. Glob Spine J. 2012;2(4):195-206. 